\title{
Perceptions and attitudes of pharmacy students towards introducing research project-based learning module in a Malaysian public university
}

\author{
RAMADAN MOHAMED ELKALMI ${ }^{1}$ http://orcid.org/0000-0002-6659-5049
}

MOHAMED HASSAN ELNAEM ${ }^{2,4 *}$ https://orcid.org/0000-0003-0873-6541

AZYYATI MOHD. SUHAIMI ${ }^{3}$

ABDULKAREEM MOHAMED ELSHAMI²

ABDULRAHMAN FATA NAHAS ${ }^{2}$ https://orcid.org/0000-0002-4879-6277

SHAZIA QASIM JAMSHED ${ }^{2}$ https://orcid.org/0000-0003-0773-0463

${ }^{1}$ College of Pharmacy and Health Sciences, University of Science and Technology of Fujairah, Fujairah, United Arab Emirates

${ }^{2}$ Department of Pharmacy Practice, Faculty of Pharmacy, International Islamic University Malaysia, Pahang, Malaysia

${ }^{3}$ Department of Pharmacy Practice, Faculty of Pharmacy, Universiti Teknologi MARA, Selangor, Malaysia

${ }^{4}$ Quality Use of Medicines Research Group, Faculty of Pharmacy, International Islamic University Malaysia

\begin{abstract}
Objectives: To explore pharmacy students' attitudes, satisfaction, and feedback regarding the introduction of a new project-based learning (PrBL) module in a Bachelor of Pharmacy (B.Pharm.) curriculum in a Malaysian public university.

Method: A pre-tested, validated 33-item web-based questionnaire was administered to third-year undergraduate pharmacy students in a Malaysian school of pharmacy $(n=102)$. The grading and assessment tools consisted of a group-based research proposal, final project presentation, and final project report. Descriptive and inferential data analyses were performed using SPSS version 22 . A $p$-value $\leq 0.05$ was considered statistically significant.

Results: There was good receptiveness, positive attitude, and satisfaction towards the PrBL module among the study participants. The vast majority of the students $(94.1 \%)$ believed that the module helped them in learning a topic that they did not know previously and found that it was fun and entertaining to work with friends. Many of students revealed that the PrBL increased their desire to learn and improve their communication skills $(76.9 \%)$. Also, they agreed that the PrBL module was suitable to prepare them for future practice and problem solving (72.5\%). About half of the students (48.0\%) expressed their desire for future courses to adopt a PrBL approach. Overall, the majority of students indicated that they were satisfied with the performance of their supervisors $(79.4 \%)$ and their supervisors made the aims and objectives of the module clear from the outset $(65.7 \%)$.

Conclusion: A new PrBL module was received with good levels of satisfaction, and it is feasible to introduce such modules in other pharmacy programmes in Malaysia. Good PrBL design, a proper educational environment, and welltrained supervisors assisted in the implementation of the module. Feedback from students and preceptors is essential in module enhancement to accommodate their evolving demands and expectations.
\end{abstract}

Keywords: Project-based Learning, Pharmacy Education, Pharmacy Practice, Malaysia

\section{Introduction}

The role of the pharmacist has expanded from the traditional role of dispensing medications to that of an integral part of the healthcare team, with an expertise in patient drug therapy management (Blouin \& Adams, 2017). Over the past two decades, the pharmacy profession has undergone a fundamental shift from a product-oriented to patient-focused model, through direct

*Correspondence: Dr. Mohamed Hassan Elnaem, Pharmacy Practice Department, Faculty of Pharmacy, International Islamic University Malaysia, Jalan Sultan Ahmad Shah, 25200 Kuantan, Pahang, Malaysia.E-mail: drmelnaem@iium.edu.my 
and indirect contribution of consumerism and advanced information technology that has reshaped the role of the pharmacist as a healthcare provider (Hibbert, Bissell, \& Ward, 2002). In order for pharmacists to perform their duties, they must be provided and equipped with essential skills to understand the current and future community primary care challenges. These qualifications and skills include having good communication skills, working in a team, and developing the capacity and adaptation for long-life effective continuing education (Hibbert et al., 2002; Chu et al., 2011). Previous studies have indicated that the use of traditional educational methods cannot achieve all the desired educational goals and objectives (Wood, 2003; Wood, 2004). It has been demonstrated that the adoption of new educational and learning strategies such as a 'project-based learning' (PrBL) approach could significantly improve and enhance the communication and teamwork skills of learners (Heyden et al., 2007; Ng et al., 2018). PrBL is an educational method focused on self-directed learning, small group discussions with facilitators, and working through problems to acquire knowledge (Van den Bergh et al., 2006). PrBL provides learners with greater autonomy and motivates them to take more responsibility to perform their tasks (Worthy, 2000; Barron et al., 2007).

Furthermore, it has the potential to incorporate real-life challenges into the learning process (Blumentfeld et al., 1991; Gordon, 1998). In this paper, PrBL is defined as a student-centred curriculum that includes an interactive approach based on structured team-based work in which students actively explore challenges and use their expertise to tackle problems in the real world (Thomas, 2000). Numerous studies have reported that it is imperative to explore the views, attitudes and get feedback from trainees and trainers about the status and operating conditions of the programme to ensure success, stability, productivity, and quality of implementation of a new learning approach (Coster et al., 2008; Elnaem et al., 2018). In this respect, this study aimed to explore the undergraduate pharmacy students' attitudes and satisfaction with the introduction of a new PrBL module in an undergraduate pharmacy programme in Malaysia. The students' feedback on the academic performance of their preceptors in running the module was also obtained.

\section{Methods}

\section{Module overview}

The study was conducted among students enrolled for the 'Research in Pharmacy and Pharmacoepidemiology' course. It is a three-credit hours core course offered during the first semester for third-year pharmacy students. The course has 132 contact hours of guided and independent learning over 14 weeks and consists of two components: (i) Research in pharmacy \& Biostatistics; and (ii) Pharmacoepidemiology. The course aims to expose the students to various issues in pharmaceutical research, introduce them to the knowledge and research methods used in pharmacoepidemiology, and concepts of drug safety and pharmacovigilance. Emphasis was placed on acquainting the students with the philosophy of research, the introduction of theory, research methodology, and practical skills necessary in conducting research. Students were also expected to understand and acquire the necessary writing skills for research proposals, reports, and scientific articles.

\section{Course delivery methods}

The total number of students enrolled for the course in the academic year 2016/2017 was 120 students. In the first week of the course, the students were briefed about the course outline, course contents, and their role throughout the course timeframe. The students were divided into ten research groups with between nine and eleven students per group. Students were assigned to research groups according to their cumulative grade point average (CGPA) in the previous semester (i.e. in the academic year 2015/2016). Each research group was supervised by a lecturer from the Department of Pharmacy Practice. The research topic for each group was determined via discussion with the respective supervisor during the first week of the semester. The actual work of the module commenced in the second week of the semester.

\section{Course evaluation and assessment}

The PrBL module was evaluated via two stages:

i) the first stage involved the proposal presentation which was carried out during the sixth week of the semester, where the students were asked to present their research proposals according to the research topics that were handed to them at the beginning of semester one of the academic session;

ii) the second stage involved the research project report submission and final presentation, where the students submitted their final project report to the course coordinator and presented their research findings in front of the lecturers and other faculty members.

The students' performance was evaluated through the research proposal presentation, final project presentation and the final project report. All students' activities were evaluated and assessed by their supervisors and the lecturers from the Department of Pharmacy Practice according to assessment rubrics.

\section{Study design}

The study was a cross-sectional, descriptive study executed through a web-based survey. Data were collected in the Kulliyyah School of Pharmacy (KOP), International Islamic University Malaysia (IIUM) during the first semester of the academic year 2016/2017. At the end of the semester, an online survey was sent by the person in charge to the e-mail addresses of third-year pharmacy students enrolled for the course using Schoology: Learning Management System (LMS). 


\section{Study subjects}

Study participants were third-year undergraduate pharmacy students enrolled for the 'Research in Pharmacy and Pharmacoepidemiology' course, and accepted to take part in the study by responding to the study instrument.

\section{Study instrument development}

The questionnaire was developed based on a comprehensive literature review and modified from previously validated instruments used to study the same topic or comparable group of students (Ibrahim, Awang, \& Razak, 1998; Hassali et al., 2009; Hong \& Yam, 2010; Elkalmi et al., 2015; Webb \& Moallem, 2016). Feedback from the lecturers involved in the teaching of research in Pharmacy and Pharmacy Practice were sought, and their comments were taken into consideration in the final draft of the questionnaire. The PrBL module was executed previously as a pilot project involving third-year undergraduate pharmacy students enrolled in the first semester of the academic year 2015-2016.

The survey was prepared and distributed in English. The final version of the questionnaire consisted of 33 questions that were divided into three sections:

- Section A included three items to collect the socio-demographic characteristics (gender, age and PrBL group) of the respondents;

- Section B consisted of 20 items that assessed students' attitudes regarding the PrBL module where respondents were asked to indicate their level of agreement using a 5 -point Likert scale $(1=$ Strongly Disagree, $2=$ Disagree, $3=$ Neutral, $4=$ Agree, $5=$ Strongly Agree);

- Section C consisted of a reduced version (10 items) of the Student Evaluation of Teaching (SET) surveys (Hong et al., 2010) where the students were asked to rate their satisfaction and give feedback on the role and performance of their supervisors using a 5-point Likert scale $(1=$ Very Dissatisfied, $2=$ Dissatisfied, $3=$ Neutral, $4=$ Satisfied, $5=$ Very Satisfied).

The content validity of the final questionnaire version was determined by the settings committee consisting of five lecturers from the Department of Pharmacy Practice. Each lecturer was asked to objectively and constructively judge the degree of relevancy using rating scale $(1=$ the issue is very irrelevant to the measured domain, $2=$ item is irrelevant to the measured domain, $3=$ the item is acceptable relevant to the measured domain, $4=$ the item is relevant to the measured domain, $5=$ the item is very relevant to the measured domain). The same was applied in assessing the degree of representativeness using rating scale $(1=$ the item is totally not representing the domain, $2=$ the item is minimally representing the domain $3=$ the item is satisfactory representing the domain, $4=$ adequately representing the domain, $5=$ the item is accurately representing the domain) for each question of the questionnaire.
The Content Validity Index (CVI) for domains attitude and satisfaction were calculated, followed by calculation of the CVI of the whole questionnaire. It was found that the CVI - relevancy, CVI - representativeness, and total CVI were $0.730,0.725$, and 0.728 , respectively (Table I). The results of CVI from five lecturers were greater than 0.5 and was thus considered acceptable. Also, the Face Validity Index (FVI) for attitude and satisfaction were measured, followed by calculation of the CVI of the whole instrument. The results showed that the FVI Clarity, FVI - comprehension, and total FVI was 0.75, 0.76 , and 0.746 , respectively. All values were well above 0.5 cut off point and thus considered acceptable (Lawshe, 1975).

The initial draft of the questionnaire was reviewed by the research team, where minor amendments were made accordingly to simplify the wording of some questionnaire items. Then the revised questionnaire was pilot-tested by administering it to a sample of 40 pharmacy students who did not participate in the study to test the validity and reliability of the survey (Table I). Respondents were asked to objectively and constructively assess the degree of clarity using a 5-point Likert scale $(1=$ the sentence is very vague, $2=$ the sentence is vague, $3=$ the sentence is acceptably clear, $4=$ the sentence is clear, $5=$ the sentence is very clear) and to assess the degree comprehension of each element using another 5-point Likert scale ( $1=$ the sentence is tough to be understood, $2=$ the sentence is hard to be understood, $3=$ the sentence is acceptable to be understood, $4=$ the sentence is easy to be understood, $5=$ sentence is very easy to be understood). The Cronbach alpha was 0.67 , which was considered acceptable.

Table I: Face and content validity index of attitude and satisfaction survey about PrBL module.

\begin{tabular}{llll}
\hline \multicolumn{1}{l}{$\boldsymbol{n} \boldsymbol{n}$} & Variables & Value \\
\hline $1 \quad$ Content Validity Index (CVI) & & \\
& & Relevancy & 0.730 \\
& & Representativeness & 0.725 \\
& & Total & 0.740 \\
\hline $2 \quad$ Face Validity Index (FVI) & & \\
& & FVI - & 0.760 \\
& Comprehension & \\
& & FVI -Clarity & 0.750 \\
& & Total & 0.746 \\
\hline
\end{tabular}

\section{Ethical approval}

The permission to conduct the study was obtained from the Dean, Faculty of Pharmacy, IIUM. Participation in the study was entirely voluntary. Agreeing to respond to the questionnaire was considered as consent. Students were also assured that their responses would be kept strictly confidential and only used for research purposes with no effect on their academic progress. 


\section{Statistical analysis}

Statistical Package for Social Sciences programme, version 22.0 (IBM SPSS Statistics for Windows, v.22; IBM Corp, USA) was used to analyse the data. Descriptive statistics were used to summarise the data. Categorical data are presented as percentages and frequencies. The age of study participants was presented as the mean $( \pm \mathrm{SD})$. Student's $t$-test and one-way ANOVA test were used to test the difference in attitude and satisfaction scores based on respondent demographics when the number of groups is equivalent to two and more than two, respectively. All statistical tests were two-tailed and maintained a significance level $(\alpha \leq 0.05)$ and a confidence interval of $\geq 95 \%$. Five-point Likert scale responses for attitude and satisfaction were collapsed into three categories to simplify comparison and understanding. So, responses of disagree and strongly disagree were signifying disagreement/ dissatisfaction, neutral responses were signifying neutrality, and responses of agreeing and strongly agree were signifying agreement/satisfaction.

Table II. Demographic characteristics of Pharmacy students enrolled in a project-based learning (PrBL) module $(\mathrm{N}=102)$

\begin{tabular}{llr}
\hline Characteristics & & $\boldsymbol{n}(\mathbf{\%})$ \\
\hline Gender & Male & $25(24.5)$ \\
& Female & $77(75.5)$ \\
\hline Age (mean) & & $22.7 \pm$ SD1.1 \\
\hline Module activities Groups & \\
& Group 1 & $10(9.8)$ \\
& Group 2 & $10(9.8)$ \\
& Group 3 & $9(8.8)$ \\
& Group 4 & $9(8.8)$ \\
Group 5 & $9(8.8)$ \\
Group 6 & $9(8.8)$ \\
Group 7 & $9(8.8)$ \\
Group 8 & $9(8.8)$ \\
Group 9 & $9(8.8)$ \\
Group 10 & $10(9.8)$ \\
Group 11 & $9(8.8)$ \\
\hline
\end{tabular}

\section{Results}

Almost all of the students $(n=102,87.1 \%)$ enrolled for the PrBL module completed the questionnaire. The mean age of the students was $22.7 \pm \mathrm{SD} 1.1$ year, where the majority were less than 24 years old $(43.4 \%)$, and more than two-thirds of the students were female $(n=77$, $75.5 \%$ ). The demographic characteristics of the respondents are summarised in Table II. Generally, the students showed positive attitudes (total mean $\pm \mathrm{SD}=$ $38.6+3.4$ ) and satisfaction (total mean $\pm \mathrm{SD}=36.9 \pm 3.9$ ) towards the module. Table III presents pharmacy students' attitudes towards PrBL module. Nearly all of the students $(n=96,94.1 \%)$ believed that the module helped them in learning a topic they did not know previously, and most of them $(n=85,83.3 \%)$ found it fun and entertaining to work with friends. Many of the students revealed that the PrBL increased their desire to learn and improved their communication skills $(n=76$, $74.5 \%$ and $n=81,79.4 \%$, respectively). The majority of them believed that PrBL could help in the development of interpersonal relations $(n=84,82.4 \%)$ and analytical thinking skills $(n=88,86.3 \%)$. Nevertheless, more than half of the students $(n=62,60.8 \%)$ disagreed with the statement that they were considered unlucky because of having to work with those who disliked conducting research, and a substantial number $(n=66,64.7 \%)$ disagreed that they do not like group work. However, study findings showed no statistically significant differences between the students' work-groups with regards to the scale of attitude and satisfaction $(p=0.261$ and $p=0.560$, respectively) as was shown in Table IV.

Table III: Pharmacy students' attitude towards project-based learning (PrBL) module $(\mathrm{N}=102)$

\begin{tabular}{|c|c|c|c|}
\hline \multirow[b]{2}{*}{ Survey item } & \multicolumn{3}{|c|}{ Degree of Response } \\
\hline & $\begin{array}{c}\text { A } \\
\text { n }(\%)\end{array}$ & $\begin{array}{c}\mathbf{N} \\
\mathrm{n}(\%)\end{array}$ & $\begin{array}{c}\text { D } \\
\text { n }(\%)\end{array}$ \\
\hline $\begin{array}{l}\text { Project-based learning helped me learn a topic I did } \\
\text { not know. }\end{array}$ & $\begin{array}{c}96 \\
(94.1)\end{array}$ & $\begin{array}{c}6 \\
(5.9)\end{array}$ & 000 \\
\hline It was fun to work with my friends. & $\begin{array}{c}85 \\
(83.3)\end{array}$ & $\begin{array}{c}15 \\
(14.7)\end{array}$ & $\begin{array}{c}2 \\
(2.0)\end{array}$ \\
\hline Project-based learning increased our desire to learn. & $\begin{array}{c}76 \\
(74.5)\end{array}$ & $\begin{array}{c}23 \\
(22.5)\end{array}$ & $\begin{array}{c}3 \\
(2.9)\end{array}$ \\
\hline $\begin{array}{l}\text { Project-based learning can improve my } \\
\text { communication skills. }\end{array}$ & $\begin{array}{c}81 \\
(79.4)\end{array}$ & $\begin{array}{c}18 \\
(17.6)\end{array}$ & $\begin{array}{c}3 \\
(2.9)\end{array}$ \\
\hline $\begin{array}{l}\text { All members of the group were active in the } \\
\text { learning phase. }\end{array}$ & $\begin{array}{c}68 \\
(66.7)\end{array}$ & $\begin{array}{c}22 \\
(21.6)\end{array}$ & $\begin{array}{c}12 \\
(11.8)\end{array}$ \\
\hline $\begin{array}{l}\text { Project-based learning made us learn by } \\
\text { investigating. }\end{array}$ & $\begin{array}{c}86 \\
(84.3)\end{array}$ & $\begin{array}{c}14 \\
(13.7)\end{array}$ & $\begin{array}{c}2 \\
(2.0)\end{array}$ \\
\hline $\begin{array}{l}\text { I was unlucky because of working with those who } \\
\text { disliked making research. }\end{array}$ & $\begin{array}{c}10 \\
(9.8)\end{array}$ & $\begin{array}{c}30 \\
(29.4)\end{array}$ & $\begin{array}{c}62 \\
(60.8)\end{array}$ \\
\hline We studied so hard. & $\begin{array}{c}78 \\
(76.5)\end{array}$ & $\begin{array}{c}22 \\
(21.6)\end{array}$ & $\begin{array}{c}2 \\
(2.0)\end{array}$ \\
\hline $\begin{array}{l}\text { Project-based learning taught us to make use of } \\
\text { knowledge. }\end{array}$ & $\begin{array}{c}89 \\
(87.3)\end{array}$ & $\begin{array}{c}12 \\
(11.8)\end{array}$ & $\begin{array}{c}1 \\
(1.0)\end{array}$ \\
\hline $\begin{array}{l}\text { Project-based learning can help us to learn } \\
\text { important topics. }\end{array}$ & $\begin{array}{c}86 \\
(48.3)\end{array}$ & $\begin{array}{c}12 \\
(11.8)\end{array}$ & $\begin{array}{c}4 \\
(3.9)\end{array}$ \\
\hline $\begin{array}{l}\text { Project-based learning can develop my } \\
\text { interpersonal relations. }\end{array}$ & $\begin{array}{c}84 \\
(82.4)\end{array}$ & $\begin{array}{c}13 \\
(12.7)\end{array}$ & $\begin{array}{c}5 \\
(4.9)\end{array}$ \\
\hline $\begin{array}{l}\text { Project-based learning can develop my analytical } \\
\text { thinking skills. }\end{array}$ & $\begin{array}{c}88 \\
(86.3)\end{array}$ & $\begin{array}{c}11 \\
(10.8)\end{array}$ & $\begin{array}{c}3 \\
(2.9)\end{array}$ \\
\hline I do not like group work. & $\begin{array}{c}10 \\
(9.8)\end{array}$ & $\begin{array}{c}26 \\
(25.5)\end{array}$ & $\begin{array}{c}66 \\
(64.7)\end{array}$ \\
\hline $\begin{array}{l}\text { I believe that Project-based learning will develop } \\
\text { my creative thinking skills. }\end{array}$ & $\begin{array}{c}75 \\
(72.6)\end{array}$ & $\begin{array}{c}24 \\
(23.5)\end{array}$ & $\begin{array}{c}3 \\
(2.9)\end{array}$ \\
\hline $\begin{array}{l}\text { I think project-based learning will contribute to our } \\
\text { work through cooperation. }\end{array}$ & $\begin{array}{c}92 \\
(90.2)\end{array}$ & $\begin{array}{c}8 \\
(8.8)\end{array}$ & $\begin{array}{c}1 \\
(1.0)\end{array}$ \\
\hline $\begin{array}{l}\text { Project-based learning, developed my } \\
\text { communication skills. }\end{array}$ & $\begin{array}{c}85 \\
(83.3)\end{array}$ & $\begin{array}{c}14 \\
(13.7)\end{array}$ & $\begin{array}{c}3 \\
(2.9)\end{array}$ \\
\hline $\begin{array}{l}\text { Project-based learning can develop my group } \\
\text { discussion skills. }\end{array}$ & $\begin{array}{c}89 \\
(87.3)\end{array}$ & $\begin{array}{c}8 \\
(7.8)\end{array}$ & $\begin{array}{c}5 \\
(4.9)\end{array}$ \\
\hline Project-based learning can speed up my learning. & $\begin{array}{c}66 \\
(64.7)\end{array}$ & $\begin{array}{c}25 \\
(24.5)\end{array}$ & $\begin{array}{c}11 \\
(10.8)\end{array}$ \\
\hline $\begin{array}{l}\text { I want my future courses to continue with project- } \\
\text { based learning. }\end{array}$ & $\begin{array}{c}49 \\
(48.0)\end{array}$ & $\begin{array}{c}42 \\
(41.2)\end{array}$ & $\begin{array}{c}11 \\
(10.8)\end{array}$ \\
\hline $\begin{array}{l}\text { I believe that project-based training will improve } \\
\text { my ability of problem-solving. }\end{array}$ & $\begin{array}{c}74 \\
(72.5)\end{array}$ & $\begin{array}{c}24 \\
(23.5)\end{array}$ & $\begin{array}{c}4 \\
(3.9)\end{array}$ \\
\hline
\end{tabular}

A=Agree; N=Neutral; D=Disagree 
Table IV: Pharmacy students' satisfaction responses $(\mathbf{N}=102)$

\begin{tabular}{|c|c|c|c|}
\hline \multirow[b]{2}{*}{ Survey item } & \multicolumn{3}{|c|}{ Degree of response } \\
\hline & $\begin{array}{c}\mathrm{S} \\
\mathrm{n}(\%)\end{array}$ & $\begin{array}{c}\mathrm{N} \\
\mathrm{n}(\%)\end{array}$ & $\begin{array}{c}\text { D } \\
\text { n (\%) }\end{array}$ \\
\hline $\begin{array}{l}\text { The staff member made the aims and objectives } \\
\text { of the course clear from the outset. }\end{array}$ & $\begin{array}{c}67 \\
(65.7)\end{array}$ & $\begin{array}{c}27 \\
(26.5)\end{array}$ & $\begin{array}{c}8 \\
(7.8)\end{array}$ \\
\hline $\begin{array}{l}\text { The staff member made the subject matter } \\
\text { interesting. }\end{array}$ & $\begin{array}{c}52 \\
(51.0)\end{array}$ & $\begin{array}{c}43 \\
(42.2)\end{array}$ & $\begin{array}{c}7 \\
(6.9)\end{array}$ \\
\hline $\begin{array}{l}\text { The staff member motivated me to do my best } \\
\text { work. }\end{array}$ & $\begin{array}{c}75 \\
(73.5)\end{array}$ & $\begin{array}{c}24 \\
(23.5)\end{array}$ & $\begin{array}{c}3 \\
(2.9)\end{array}$ \\
\hline $\begin{array}{l}\text { The staff member provided adequate } \\
\text { opportunities for me to pursue my own learning. }\end{array}$ & $\begin{array}{c}80 \\
(78.4)\end{array}$ & $\begin{array}{c}20 \\
(19.6)\end{array}$ & $\begin{array}{c}2 \\
(2.0)\end{array}$ \\
\hline $\begin{array}{l}\text { The staff member helped me to develop my } \\
\text { understanding of concepts and principles. }\end{array}$ & $\begin{array}{c}80 \\
(78.4) \\
\end{array}$ & $\begin{array}{c}17 \\
(16.7)\end{array}$ & $\begin{array}{c}5 \\
(4.98) \\
\end{array}$ \\
\hline $\begin{array}{l}\text { The staff member displayed a genuine interest in } \\
\text { my learning needs and progress. }\end{array}$ & $\begin{array}{c}81 \\
(79.4)\end{array}$ & $\begin{array}{c}19 \\
(18.6)\end{array}$ & $\begin{array}{c}2 \\
(2.0)\end{array}$ \\
\hline $\begin{array}{l}\text { The staff member gave me helpful feedback on } \\
\text { how I was going. }\end{array}$ & $\begin{array}{c}83 \\
(81.4)\end{array}$ & $\begin{array}{c}17 \\
(16.7)\end{array}$ & $\begin{array}{c}2 \\
(2.0)\end{array}$ \\
\hline $\begin{array}{l}\text { The staff member used up-to-date teaching and } \\
\text { learning approaches. }\end{array}$ & $\begin{array}{c}79 \\
(77.5)\end{array}$ & $\begin{array}{c}20 \\
(19.6)\end{array}$ & $\begin{array}{c}3 \\
(2.9)\end{array}$ \\
\hline $\begin{array}{l}\text { The staff member made it clear how her/his } \\
\text { teaching developed the qualities of IIUM } \\
\text { undergraduate. }\end{array}$ & $\begin{array}{c}70 \\
(68.8)\end{array}$ & $\begin{array}{c}28 \\
(27.5)\end{array}$ & $\begin{array}{c}4 \\
(3.9)\end{array}$ \\
\hline $\begin{array}{l}\text { Overall, I was satisfied with the performance of } \\
\text { this staff member. }\end{array}$ & $\begin{array}{c}81 \\
(79.4)\end{array}$ & $\begin{array}{c}17 \\
(16.7)\end{array}$ & $\begin{array}{c}4 \\
(3.9)\end{array}$ \\
\hline
\end{tabular}

S=Satisfied; $\mathbf{N}=$ Neutral; D=Dissatisfied

Table V: Variation in pharmacy students' attitudes and satisfactions regarding introducing project-based learning (PrBL) module $(\mathrm{N}=102)$

\begin{tabular}{|c|c|c|c|c|c|}
\hline & n (\%) & & Mean & SD & $p$-value \\
\hline Male & $25(24.5)$ & \multirow{2}{*}{ ATTITUDE } & 51.12 & 5.9 & \multirow{2}{*}{$\mathbf{0 . 1 7 3}^{*}$} \\
\hline Female & $7(75.5)$ & & 53.48 & 5.9 & \\
\hline Male & 25 & \multirow{2}{*}{ SATISFACTION } & 26.76 & 3.0 & \multirow{2}{*}{$0.793^{*}$} \\
\hline Female & 77 & & 27.00 & 4.1 & \\
\hline Group 1 & 10 & \multirow{11}{*}{ ATTITUDE } & 53.00 & 4.52 & \multirow{11}{*}{$0.187^{* *}$} \\
\hline Group 2 & 10 & & 50.30 & 7.79 & \\
\hline Group 3 & 9 & & 59.89 & 18.13 & \\
\hline Group 4 & 9 & & 54.11 & 2.57 & \\
\hline Group 5 & 9 & & 54.11 & 3.26 & \\
\hline Group 6 & 9 & & 49.11 & 6.07 & \\
\hline Group 7 & 9 & & 50.00 & 5.87 & \\
\hline Group 8 & 9 & & 51.55 & 7.50 & \\
\hline Group 9 & 9 & & 52.78 & 4.74 & \\
\hline Group 10 & 10 & & 53.60 & 4.11 & \\
\hline Group 11 & 9 & & 53.67 & 3.04 & \\
\hline Group 1 & 10 & \multirow{12}{*}{ SATISFACTION } & 25.10 & 6.31 & \multirow{12}{*}{$\mathbf{0 . 5 8 0}^{* *}$} \\
\hline Group 2 & 10 & & 25.70 & 4.29 & \\
\hline Group 3 & 9 & & 27.89 & 3.59 & \\
\hline Group 4 & 9 & & 27.11 & 3.82 & \\
\hline Group 5 & 9 & & 26.89 & 3.76 & \\
\hline Group 6 & 9 & & 26.44 & 3.90 & \\
\hline Group 7 & 9 & & 29.22 & 0.97 & \\
\hline Group 8 & 9 & & 27.11 & 3.33 & \\
\hline Group 9 & 9 & & 25.67 & 5.61 & \\
\hline Group 10 & 10 & & 28.10 & 2.02 & \\
\hline Group 11 & 9 & & 27.33 & 2.60 & \\
\hline Total & 102 & & 26.94 & 3.92 & \\
\hline
\end{tabular}

SD=Standard Deviation; ${ }^{*}$ - Students t-test; ${ }^{* *}$ - one-way ANOVA test
The responses to questions related to the Student Evaluation of Teaching (SET) feedback survey are shown in Table V. It was shown that many of the students $(n=67$, $65.7 \%$ ) believed that their supervisors made the aims and objectives of the module clear from the outset. About two-thirds of them $(n=75,73.5 \%)$ indicated that their supervisor motivated them to do their best work. Almost all of the students were satisfied with the module, facilities and the instruction provided to them throughout the semester and many of study respondents $(n=81$, $79.4 \%$ ) revealed that they were satisfied with the performance of their supervisors.

\section{Discussion}

To the best of the authors' knowledge, this is the first study which discusses and explores pharmacy students' attitudes and satisfaction and captures their feedback regarding introducing a new PrBL module into the undergraduate pharmacy programme in Malaysia. Overall, the majority of respondents expressed positive attitudes towards the new PrBL module introduction. Taking into account the age difference and study course, the findings of the current study are in agreement with the findings of previous studies conducted in Greece and Turkey (Kaldi, Filippatou, \& Govaris, 2011; Ciftci, 2015). Furthermore, the study findings suggest the module was successful in instilling the students with a positive attitude towards the provision and the philosophy of the PrBL concept. The current module has been well received among the respondents, giving the impression that it can be applied and introduced in various pharmacy training programmes throughout the country in the future. PrBL can offer tools to measure the skill sets and attitudes that are usually not measured using a standardised method (Gardner, 2006; Horpyniuk, 2015). Many of the students believed that the PrBL implementation enables them to optimise the use of acquired knowledge and would be useful to develop and improve their interpersonal relations as well as their analytical thinking skills. The study results are consistent with previous studies, which reported that PrBL could enhance students' creative thinking skills and contribute significantly to building teamwork skills in various disciplines of education (Hall \& Weaver, 2001; Bell, 2010).

Furthermore, it enhances learners' acquired knowledge and strengthens personal skills and spirit of cooperation (Frank, Lavy, \& Elata, 2003). Frank et al. affirmed that PrBL provides adequate teamwork opportunities in various learning environments (Frank et al., 2003), and thus is regarded as a modern experiential learning approach that can improve knowledge and skills among learners (Major \& Palmer, 2001; Efstratia, 2014). Almost all study participants admitted that PrBL developed and improved their communication skills, which is consistent with results reported by Awang et al. (2015), where study participants who were generally motivated by the module demonstrated good communication skills among themselves (Awang \& 
Daud, 2015). Previous studies' findings are also consistent with the fact that the majority of this study's respondents believe that the PrBL accelerates their learning process (Webb \& Moallem, 2016; Serdyukov, 2018). A substantial number of the students expressed their desire to continue their future courses with PrBL, which reaffirm the good reception of the module among pharmacy students (Doppelt, 2003). The results from the SET survey which has been set up to objectively assess the pharmacy students' satisfaction on the contribution, role, and performance of the preceptors (Crumbley, Henry, \& Kratchman, 2001; Hong \& Yam, 2010) indicated that almost all of the students were satisfied. These promising results are encouraging to future efforts to develop such a module and adapt it to the various disciplines of pharmaceutical education. Although the preceptors have been briefed about the operational aspects of the module, it was demonstrated that about half of the students were equivocal about whether the preceptors made the subject matters interesting. This result may be explained by other external factors that have not been considered in this study, such as the attitudes and timing of implementation of the module, and the readiness of the student to such new activity that they were not familiar with or accustomed to.

Additionally, these findings might be attributed to the students' frustration with their academic performance in the other simultaneous integrated courses. Therefore, the preceptors should take the necessary steps to acclimatise their students to the inherent benefits of this new teaching approach. The students should be generally allowed to provide information that can be integrated into the teaching assessment process to overcome the behavioural problems of preceptors and to improve the quality of training. Preceptors are highly recommended to undergo intensive training prior to the programme implementation.

\section{Limitation}

A key limitation of this study is that only pharmacy students at one public university were included, and, therefore, the results cannot be generalised to all pharmacy students in Malaysia. Selection bias is a possibility. In addition, preceptors' perceptions and opinions towards the module process, however, were not explored and included in the current study. Although the findings of this study would be a valuable addition to existing literature, it should be interpreted within the confinements and limitations of the study and the environment where the study has been executed.

\section{Conclusion}

Study findings showed good receptiveness to the PrBL module among pharmacy students, as reflected by the positive attitude and good levels of satisfaction with it. It was shown that the preceptors have actively contributed to the students' integration and facilitated their understanding of $\mathrm{PrBL}$ concepts during the module implementation. This study could serve as a baseline to promote more innovative approaches in pharmacy education aimed to provide pharmacy students with the essential skills to successfully deal with the real-world problem and enhance their role in providing better pharmaceutical care. Further enhancements in the design, content, procedure, and assessment are necessary to improve the quality of implementation. It would be valuable to conduct further research covering various programmes and university levels to accommodate the experiment within the national education policy.

\section{Acknowledgments}

We extend our appreciation to the students who took part in this study and also the dean and staff of Kulliyyah of Pharmacy, International Islamic University Malaysia, for providing the enabling environment to conduct this study.

Funding: The study received no grant from any funding agency

\section{References}

Awang, H., \& Daud, Z. (2015). Improving a Communication Skill Through the Learning Approach Towards the Environment of Engineering Classroom. Procedia - Social and Behavioral Sciences, 195, 480486. doi: https://doi.org/10.1016/j.sbspro.2015.06.241

Barron, B., Schwartz, D., Vye, N., Moore, A., Petrosino, A., Zech, L., \& Bransford, J. (2007). Doing With Understanding: Lessons From Research on Problem and Project-Based Learning. Journal of the Learning Sciences, 7(3), 271-311. doi: https://doi.org/10.1207/ s15327809j1s0703\&4_2

Bell, S. (2010). Project-Based Learning for the 21st Century: Skills for the Future. The Clearing House: A Journal of Educational Strategies, Issues, and Ideas, 83(2), 39-43. doi: https://doi.org/10.1080/00098650903505415

Blouin, R.A., \& Adams, M.L. (2017). The Role of the Pharmacist in Health Care: Expanding and Evolving. North Carolina Medical Journal, 78(3), 165-167. doi: https://doi.org/10.18043/ncm.78.3.165

Blumentfeld, P.C., Soloway, E., Marx, R.W., Krajcik, J.S., Guzdial, M., \& Palincsar, A. (1991). Motivating projectbased learning: sustaining the doing, supporting the learning. Educational Psychologist, 26(3-4), 369-398

Chu, S.K.W., Tse, S.K., Loh, E.K.Y., \& Chow, K. (2011). Collaborative inquiry project-based learning: Effects on reading ability and interests. Library and Information Science Research, 33(3), 236-243. doi: https://doi.org/ $\underline{10.1016 / \text { j.lisr.2010.09.008 }}$ 
Ciftci, S. (2015). The Effects of Using Project-Based Learning in Social Studies Education to Students' Attitudes towards Social Studies Courses. Procedia Social and Behavioral Sciences, 186, 1019-1024. doi: https://doi.org/10.1016/j.sbspro.2015.04.205

Coster, S., Norman, I., Murrells, T., Kitchen, S., Meerabeau, E., Sooboodoo, E., \& d'Avray, L. (2008). Interprofessional attitudes amongst undergraduate students in the health professions: A longitudinal questionnaire survey. International Journal of Nursing Studies, 45(11), 1667-1681. doi: https://doi.org/10.1016/ j.ijnurstu.2008.02.008

Crumbley, L., Henry, B.K., \& Kratchman, S.H. (2001). Students' perceptions of the evaluation of college teaching. Quality Assurance in Education, 9(4), 197-207. doi: https://doi.org/10.1108/EUM0000000006158

Doppelt, Y. (2003). Implementation and assessment of project-based learning in a flexible environment. International Journal of Technology and Design Education, 13(3), 255-272. doi: https://doi.org/10.1023/ A:1026125427344

Efstratia, D. (2014). Experiential Education through Project Based Learning. Procedia - Social and Behavioral Sciences, 152, 1256-1260. doi: https:// doi.org/10.1016/j.sbspro.2014.09.362

Elkalmi, R.M., Alshami, A.K.M., Ahmad, A., Khan, M.U., Rahman, N.S.A., \& Alkoudmani, R.M. (2015). Assessment of learning style preferences of pharmacy students: Findings from public university of Malaysia. Indian Journal of Pharmaceutical Education and Research, 49(4), 266-271. doi: https://doi.org/10.5530/ ijper.49.4.4

Elnaem, M.H., Bin Che Ibrahim, M.Z., Abdul Rahman, N.A.H., Binti Mahyidin, N.H., Binti Sulaiman, N.M., \& Binti Zulkiflee, F.A. (2018). Knowledge and perceptions toward cardiology pharmacy education and training: Malaysian pharmacy students' perspectives. Currents in Pharmacy Teaching and Learning, 10(4), 453-462. doi: https://doi.org/10.1016/j.cptl.2017.12.019

Frank, M., Lavy, I., \& Elata, D. (2003). Implementing the project-based learning approach in an academic engineering course. International Journal of Technology and Design Education, 13(3), 273-288. doi: https:// doi.org/10.1023/A:1026192113732

Gardner, H.E. (2006). Multiple Intelligences: New Horizons in Theory and Practice (online). Available at: https://scholar.google.com/scholar?hl=en\&as_sdt $=0 \% 2 \mathrm{C} 5 \& \mathrm{q}$ $=$ Gardner $+\mathrm{HE}$. + Multiple + intelligences $\% 3 \mathrm{~A}+\mathrm{New}+$ horizons + in + theory+and+practice. + New + York $\% 3 \mathrm{~A}+$ Basic + books $\% 3 \mathrm{~B}+2008$. $+320+$ p.\&btnG $=$. Accessed 20th May, 2020

Gordon, R. (1998). Balancing Real-World Problems with Real-World Results. Phi Delta Kappan, 79(5), 390. Available at: https://www.questia.com/read/ 1G1-20371169/balancing-real-world-problems-with-realworld-results. Accessed 20th May, 2020
Hall, P., \& Weaver, L. (2001). Interdisciplinary education and teamwork: A long and winding road. Medical Education, 35(9), 867-875. doi: https://doi.org/ 10.1046/j.1365-2923.2001.00919.x

Hassali, M.A., Shafie, A.A., Awaisu, A., Izham, M., Ibrahim, M.I.M., \& Ahmed, S.I. (2009). A Public Health Pharmacy Course at a Malaysian Pharmacy School. American Journal of Pharmaceutical Education, 73(7), Art.136. doi: 10.5688/aj7307136

Heyden, Y. Vander, Deconinck, E., Vannecke, C., Questier, F., Van Gyseghem, E., \& Massart, D.L. (2007). Skills development by project-based education in the food and diet course of a pharmacy program. Pharmacy Education, 7(3), 235-238. doi: https:// doi.org/10.1080/15602210701463718

Hibbert, D., Bissell, P., \& Ward, P.R. (2002). Consumerism and professional work in the community pharmacy. Sociology of Health and Illness, 24(1), 4665. https://doi.org/10.1111/1467-9566.00003

Ibrahim, M.I.M., Awang, R., \& Razak, D.A. (1998). Introducing social pharmacy courses to pharmacy students in Malaysia. Medical Teacher, 20(2), 122-126. doi: https://doi.org/10.1080/01421599881228

Kaldi, S., Filippatou, D., \& Govaris, C. (2011). Projectbased learning in primary schools: Effects on pupils' learning and attitudes. Education 3-13, 39(1), 35-47. doi: https://doi.org/10.1080/03004270903179538

Lawshe, C.H. (1975). Quantitative Approach To Content Validity. Personal Psychology, 28, 563-575

Major, C.H., \& Palmer, B. (2001). Academic Exchange Quarterly Spring 2001 : Volume 5, Issue 1 Assessing the Effectiveness of Problem Based Learning in Higher Education: Lessons from the Literature. Academic Exchange Quarterly, 5(1), 4-9. Available at: http:// www.rapidintellect.com/AEQweb/mop4spr01.htm

Ng, L., Cullum, S., Cheung, G., \& Friedman, S.H. (2018). Transforming an idea into a scholarly project. Australasian Psychiatry, 26(2), 210-213. doi: https:// doi.org/10.1177/1039856217751985

Serdyukov, P. (2018). Innovation in education: what works, what doesn't, and what to do about it? Journal of Research in Innovative Teaching \& Learning, 10(1), 4-33. doi: https://doi.org/10.1108/jrit-10-2016-0007

Thomas, J. W. (1983). A Review of Research on Lecturing. Higher Education Research \& Development, 2 ( 1 ), $63-78$. https://doi.org/ $\underline{10.1080 / 0729436830020105}$

Van den Bergh, V., Mortelmans, D., Spooren, P., Van Petegem, P., Gijbels, D., \& Vanthournout, G. (2006). New Assessment Modes Within Project-Based Education - the Stakeholders. Studies in Educational Evaluation, 32(4), 345-368. doi: https://doi.org/ 10.1016/j.stueduc.2006.10.005 
Webb, A., \& Moallem, M. (2016). Feedback and feedforward for promoting problem-based learning in online learning environments. Malaysian Journal of Learning and Instruction, 13(2), 1-41. doi: 10.32890/ mjli2016.13.2.1

Wood, D.F. (2003). ABC of learning and teaching in medicine: problem based learning. British Medical Journal, 326(7385), 385-387. doi: https://doi.org/ $\underline{10.1136 / \mathrm{bmj} .326 .7385 .385}$

Wood, E. J. (2004). Problem-based learning* . Acta Biochimica Polonica, 51(2), 21-26

Worthy, M.J. (2000). Conducting research on topics of student interest. Reading Teacher, 54(3), 298-299 